\title{
Mycosis Fungoides and Sezary Syndrome N1a TNM Finding v7
}

National Cancer Institute

\section{Source}

National Cancer Institute. Mycosis Fungoides and Sezary Syndrome N1a TNM Finding v7. NCl Thesaurus. Code C88239.

Clone negative. Note: A T-cell clone is defined by PCR or Southern blot analysis of the Tcell receptor gene. (from AJCC 7th Ed.) 